\title{
Benefits of Menaming Dams and Potential of Irrigation Canals as a Source of Power Generation
}

\author{
Yuli Handika, ${ }^{a}$ and Asral, ${ }^{b^{*}}$ \\ a) Postgraduate Student in Mechanical Engineering, Universitas Riau, Indonesia \\ b) Mechanical Engineering, Universitas Riau, Indonesia \\ *Corresponding author: asral@lecturer.unri.ac.id
}

\section{Paper History}

Received: 01-October-2021

Received in revised form: 29-November-2021

Accepted: 30-November-2021

\begin{abstract}
The difficult location access and a small population can cause lack of electricity from PLN (State Electricity Company). One alternative that can be done is to use irrigation canals as a source of generation. In this study explained the social conditions of the community, the function of dams for the community and the potential of irrigation canals as a source of power generation. A case study was conducted in the Menaming Village in Riau Province. Menaming dam is one of the dams that have two main irrigation channels that can be used as a source of power generation. A quantitative descriptive method was used in this study. The results of the survey conducted by observing directly, questionnaires and data collection showed that Menaming dam was very beneficial for the Menaming's community. Menaming dam is used as a source of water for rice fields and community ponds, access to community plantation land, fishing grounds and as a tourist attraction. Based preliminary study in Menaming dam was discovered the hydraulic water power in irrigation canals amounted to 1,330 watts. Therefore, it can be used as a source of power generation to meet the electricity needs of a simple house.
\end{abstract}

KEY WORDS: Menaming dams, Irrigation canals, Hydrolysis power water.

\section{NOMENCLATURE}

$P L N \quad$ State Electricity Company

PLTMH Micro Hydro Power Plant

DAS Watershed

$k W \quad$ Kilowatt

$Q \quad$ Flow Debit

$\begin{array}{ll}A & \text { Channel Cross Section Area } \\ V & \text { Flow Speed } \\ P h & \text { Hydraulic Potential } \\ \rho & \text { Mass of Water Type } \\ g & \text { Acceleration of graffiti } \\ h & \text { Channel Slope }\end{array}$

\subsection{INTRODUCTION}

Worldwide, more than one billion people are without access to electricity, according to a report published by the International Energy Agency in 2017 [1]. Despite efforts from the government through a program to provide electricity to the community, there are still many areas that have not been electrified by PLN. This is due to several factors, including access to difficult locations and also uneven distribution of residents so that it is difficult to flow PLN electricity. One of the alternatives that can be used as a power plant alternative is the Micro Hydro Power Plant (PLTMH) [2]. The selection of the type of river flow is an important factor before building a mini-hydro power plant. The river flow must have relatively stable flow characteristics throughout the year to produce stable electricity output.

The PLTMH utilizes running hydropower and converted into a mechanical form to generate electricity using a generator [3]. Power capacity used in Micro Hydro power plants below $100 \mathrm{~kW}[1],[4]-[9]$. Thus is very suitable to be applied to areas that have many rivers and irrigation channels because it can be applied in accordance with the potential of water in the area.

Menaming Village Rambah District Rokan Hulu district is in the upper watershed Menaming. Menaming watershed is a sub-watershed Rokan Kanan in Riau Province. Menaming Village is already affordable by lighting from PLN. However, some areas of the village are far from PLN's circuit network. It is still not electrified. Therefore, to meet the needs of electricity may be used alternative energy sources. One of the alternative energy sources is an energy derived from the water resources.

In this research aim is to discuss the potential of PLTMH in the irrigation canal of Menaming dam in Riau Province. Furthermore, it can be known the power capacity produced and 
also the impact of construction of the PLTMH on the economic and social community.

\subsection{METHOD}

The study was conducted in Menaming village using quantitative descriptive method. This type of research is exploratory research, which begins to explore the theories and concepts of managing and utilizing irrigation canals, flow discharge calculation, water power calculation, and explores the state of society and the environment around Menaming dam through a survey.

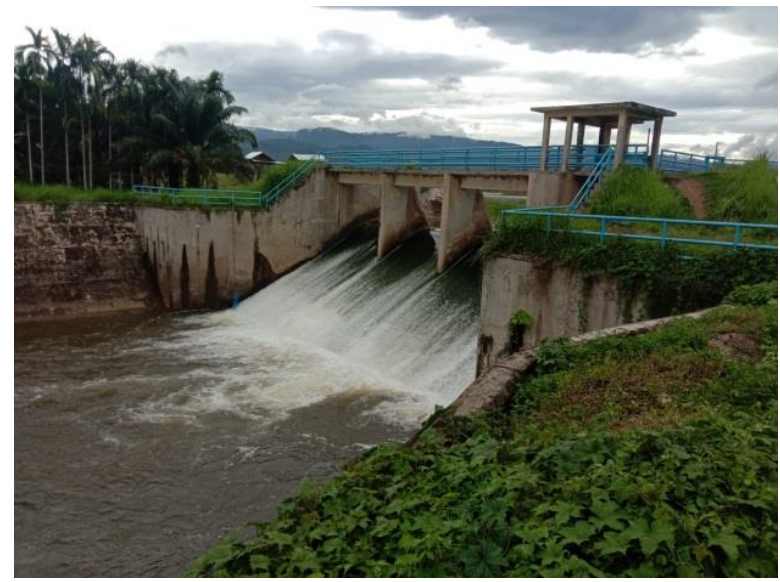

Figure 1: Menaming dam

\subsection{Flow Debit Calculation}

The flow discharge is the amount of water that passes through a cross-section per unit of time [10]. Calculation of flow discharge is done by collecting data that contains measurements of water height, water speed, and also crosssectional measurements at the time of measurement. Because the measurement is done several times, then it is taken for the flow discharge calculation of a measure when normal conditions in the state of the channel door are not clogged with wood or garbage. The tools used in this data retrieval are stopwatches, meters, and wooden beams to measure the depth of water in irrigation canals. To calculate flow debit is used equation [11]:

$Q=A \times V$

Where:

$Q=\operatorname{Debit}\left(\mathrm{m}^{3} / \mathrm{s}\right)$

$A=$ Cross-sectional area of the river $\left(\mathrm{m}^{2}\right)$

$V=$ Average flow speed $(\mathrm{m} / \mathrm{s})$

\section{Measure the flow speed of irrigation canals (V)}

The steps used to get the speed of water flow in the irrigation canal is used a buoy and wash it in the irrigation canal. Then, use a stopwatch to calculate the time it takes the buoy to reach a distance of one meter[12].

\section{Measuring channel cross-sectional area (A)}

Trapezoidal cross-sectional shapes are used for large discharges and generally for draining rainwater, domestic waste and irrigation [13]. Measurement of cross-sectional measurement of irrigation canals uses meters to take the dimensions of the cross-section. After the cross-sectional dimension is obtained, then the equation is used to get the cross-sectional area of the channel [13].

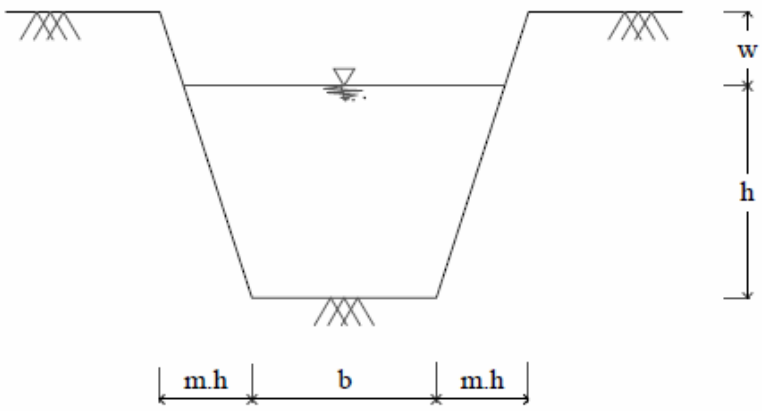

Figure 2: Trapezoidal shape channel [13]

For trapezoidal cross-sections the wet cross-section (A), wet circumference $(\mathrm{P})$, hydrolytic radius $(\mathrm{R})$ is calculated by the equation [13]:

$$
\begin{aligned}
& A=(b+m h) h \\
& P=b+\left(2 x h \sqrt{m^{2}+1}\right)
\end{aligned}
$$

Once the area and speed of river flow is known, the amount of discharge in the irrigation canal can be analyzed.

\section{Calculation (h)}

To find out the slope of irrigation canals is done by juxtaposing the water level of the reservoir with irrigation canal water at the location to be built PLTMH. Technical measurement is done by measuring flatness using water scales, and measuring the difference using meters.

\subsection{Water Hydraulic Power Calculation (Ph)}

To get the capacity of the generator to be used in the plant, it is necessary to know the hydraulic potential of irrigation water. Hydraulic potential calculated by equation [14]:

$P h=\rho \times g \times Q \times h$

Where:

$P h=$ Hydraulic potential $(\mathrm{kW})$

$\rho=$ Water density $\left(1,000 \mathrm{~kg} / \mathrm{m}^{3}\right)$

$g=$ Graphite acceleration $\left(\mathrm{m} / \mathrm{s}^{2}\right)$

$Q=$ Water discharge $\left(\mathrm{m}^{3} / \mathrm{s}\right)$

$h=$ Slope of the river $(\mathrm{m})$

\subsection{Exploration of Society State}

The instruments to exploration of society state are used questionnaires and interviews. Questionnaires and interviews were given to the sampled villagers (homeowners), village officials, community leaders and communities far from the dam in Menaming Village. This interview and questionnaire contains several questions to find out things related to dams, both its benefits and its effect on the activities of the Menaming village community. 


\subsection{RESULT AND DISCUSSION}

\subsection{Topographic Survey}

The location of Menaming Dam is located in Menaming Village rambah district of Rokan Hulu regency. This dam is located at a distance of $3 \mathrm{Km}$ from the Settlement of Residents. At this dam empties into two rivers, namely the Aek Matua River and the Menaming River. The dam is connected by road from Menaming village. Very close to the main road.

Irrigation flow is not dependent on the season because the flow discharge arrangement is in the dam opening but the flow discharge is in line with the needs of community rice fields. For example, during the plowing and planting of rice, the flow discharge is raised. While at the time of harvest the flow discharge is reduced. Menaming dam is located at $0^{\circ} 51^{\prime} 54.38^{\prime \prime} \mathrm{N}$ and $100^{\circ} 02^{\prime} 40.33^{\prime \prime} \mathrm{E}$.

\subsection{Socio-Economic Survey}

Dams as community access to bring agricultural products and fishing places. Because there is no adequate road to the community garden, the dam is also used as an access to issue plantation products by boat. The location of Menaming dam is an intermediary between community gardens and also villages. So, the existence of this dam is a very important location for community activities.

Menaming dams also have a supportive ecosystem as a breeding ground because of the flow of unsalted tributaries. This dam is still many local fish that used as side dishes. Many of the residents are looking for fish in this dam, both for sale and for consumption (Figure 3-4). In order to increase people's income, the dam is also used as a tourist attraction (Figure 5). Over time, more and more tourists come to this dam, both local people and from outside the area.

For the community, this dam greatly affects the economic condition of the community because the water from this irrigation canal is used as a source of water for fish ponds and also community rice fields. Because the location is very important, many people who sell and make this location as their livelihood. Within a radius of 100 meters from the dam there are two houses occupied and some houses that are only occupied by the community on harvest day. This is because there is no electricity that reaches the location.

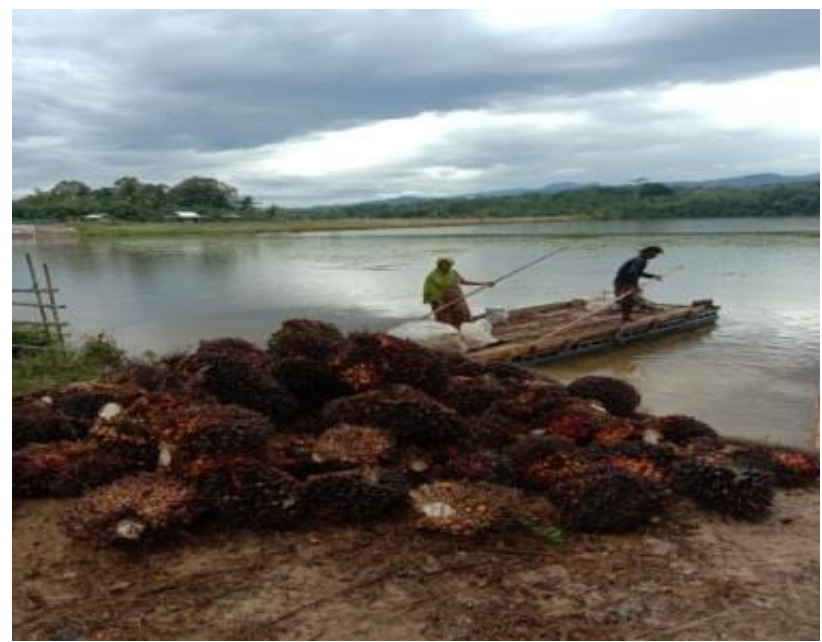

Figure 3: Dams as community access

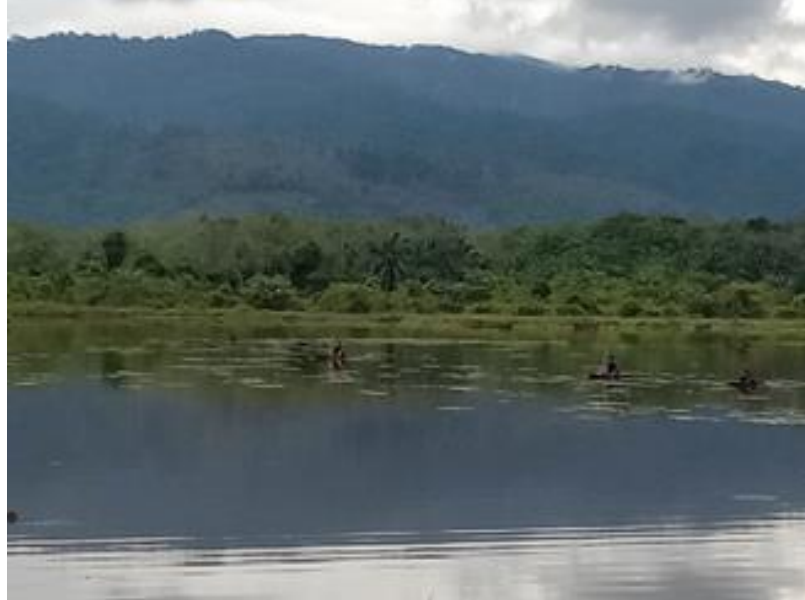

Figure 4: Dam as a place to find fish

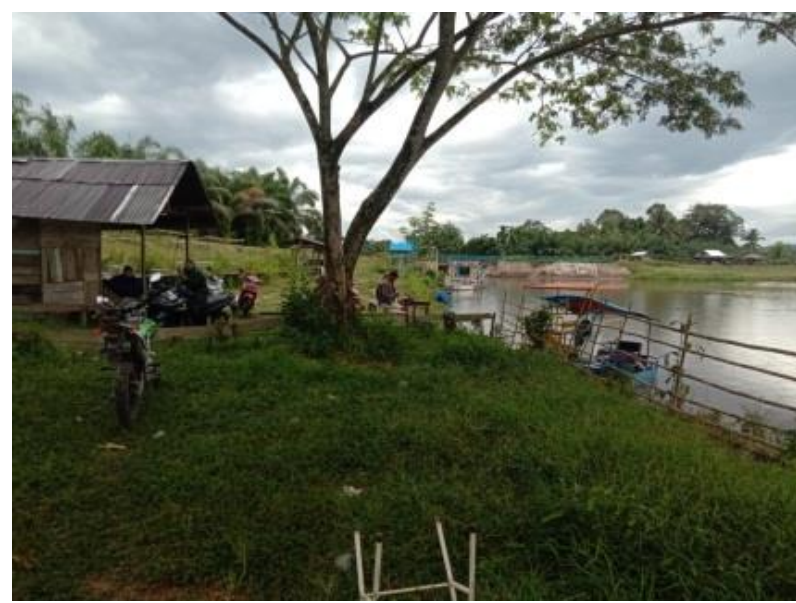

Figure 5: Dam as a tourist attraction

\subsection{Flow Debit Measurement}

Flow discharge measurements are carried out in locations close to people's homes. This aims the construction of power plants can be utilized directly by

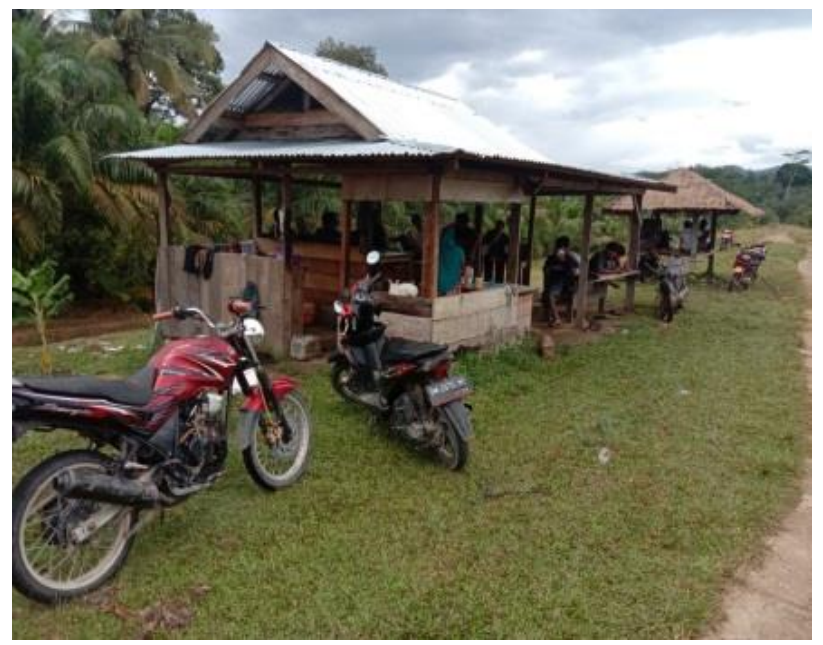

Figure 6: Dams as a place to trade 
the community and easier to find information about what factors affect changes in irrigation canal flow discharge. These measurements are carried out every week to get more tangible results. From the flow debit measurement conducted from September 5, 2021 to November 29, 2021. The flow debit data was obtained according to Table 1 . From the measurement of field results, there is a difference in flow discharge in irrigation canals. This is due to the closure of the irrigation canal door by wood especially in the moments after rain.

Table 1: Irrigation canal flow debit

\begin{tabular}{clcccc}
\hline No & Day & Date & $\begin{array}{c}\text { Water } \\
\text { Speed } \\
(\mathrm{m} / \mathrm{s})\end{array}$ & $\begin{array}{c}\text { Water } \\
\text { Dept } \\
(\mathrm{m})\end{array}$ & $\begin{array}{c}\text { Flow } \\
\left(\mathrm{m}^{3}\right)\end{array}$ \\
\hline 1 & Sunday & 05-Sep-21 & 0.31 & 0.42 & 0.16 \\
2 & Sunday & 12-Sep-21 & 0.32 & 0.50 & 0.21 \\
3 & Sunday & 19-Sep-21 & 0.39 & 0.64 & 0.36 \\
4 & Sunday & 26-Sep-21 & 0.39 & 0.64 & 0.36 \\
5 & Thursday & 30-Sep-21 & 0.35 & 0.55 & 0.26 \\
6 & Thursday & 07-Oct-21 & 0.35 & 0.55 & 0.26 \\
7 & Thursday & 14-Oct-21 & 0.39 & 0.64 & 0.36 \\
8 & Thursday & 21-Oct-21 & 0.44 & 0.70 & 0.46 \\
9 & Sunday & 31-Oct-21 & 0.39 & 0.64 & 0.36 \\
10 & Thursday & 04-Nov-21 & 0.39 & 0.64 & 0.36 \\
11 & Thursday & 11-Nov-21 & 0.45 & 0.67 & 0.44 \\
12 & Friday & 19-Nov-21 & 0.45 & 0.67 & 0.44 \\
\hline
\end{tabular}

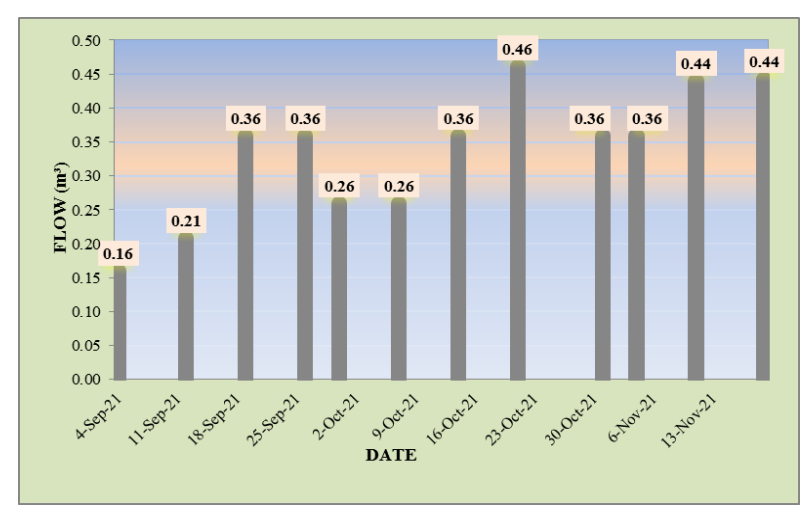

Figure 7: Irrigation canal flow discharge

\subsection{Calculation of Hydraulic Power of Water}

To get the hydraulic power of water, previously must be obtained the slope of the irrigation canal. Because the irrigation canals were surveyed more to irrigation canals with a small slope, the calculation is the difference in water levels in dams and irrigation canals. From the measurements taken, there was a difference in height of $30 \mathrm{~cm}$.

After the slope and discharge of the flow was obtained, to look for the hydraulic potential of water, then the Equation 4 was used.

$$
\begin{aligned}
& P h=\rho \times g \times Q \times h \\
& P h=1000 \times 10 \times 0.22 \times 0.3 \\
& P h=660 \text { Watt } .
\end{aligned}
$$

\subsection{CONCLUSION}

From the research conducted, several conclusions can be drawn, among others:

- The development of the population of the Menaming village community in the future will lead around the Menaming dam.

- The flow of the dam irrigation canal is not dependent on the season.

- The open door of the irrigation canal door is very dependent on the rice planting period. So, the calculation of hydraulic potential measurement data should be taken during the rice planting period ranging from rice plugging to the rice harvest period. Therefore, the minimal and maximum flow discharge can be taken into account.

- Although the hydraulic potential of irrigation canal water is relatively small, it can be applied to meet the needs of one community house.

\section{REFERENCES}

[1] Sanampudi, N \& Kanakasabapathy, P. (2021). Integrated voltage control and frequency regulation for stand-alone micro-hydro power plant, Mater. Today Proc., 46(10), 5027-5031, doi: 10.1016/j.matpr.2020.10.403.

[2] Purnama, A. (2018). Analisis kelayakan pembangkit listrik tenaga mikrohidro (PLTMH) tinjauan teknis, Jurnal Riset Kajian Teknologi dan Lingkungan, 1(2), 124-130.

[3] Jawahar, C.P. \& Michael, P.A. (2015). A review on turbines for micro hydro power plant, Renewable Sustainable Energy Review, 72, 882-887.

[4] Gagliano, A., Tina, G.M., Nocera, F. \& Patania, F. (2014) Technical and economic perspective for repowering of micro hydro power plants: A case study of an early XX century power plant, Energy Procedia, 62, 512-521, doi: 10.1016/j.egypro.2014.12.413.

[5] Rompas, P.T.D. (2011). Analisis pembangkit listrik tenaga mikrohidro (PLTMH) pada daerah aliran Sungai Ongkak Mongondow di Desa Muntoi Kabupaten Bolaang Mongondow, Jurnal Penelitian Saintek, 16(2), 160-171.

[6] Ozdemir, M.T. \& Orhan, A. (2012). An experimental system for electrical and mechanical education: micro hydro power plant prototype, Procedia-Social Behavior Science 47, 2114-2119, doi:10.1016/j.sbspro.2012.06.959.

[7] Nazir, R., Laksono, H.D., Waldi, E.P., Ekaputra, E. \& Coveria, P. (2014). Renewable energy sources optimization: A micro-grid model design, Energy Procedia, 52, 316-327, doi:10.1016/j.egypro.2014.07.083.

[8] Michael, P.A. \& Jawahar, C.P. (2017). Design of $15 \mathrm{kw}$ Micro Hydro Power Plant for Rural Electrification at Valara, Energy Procedia, 117, 163-171, doi: 10.1016/j.egypro.2017.05.119.

[9] Zema, D.A., Nicotra, A., Tamburino, V. \& Zimbone, S.M. (2016). A simple method to evaluate the technical and economic feasibility of micro hydro power plants in existing irrigation systems, Renewable Energy, 85, 498506, doi:10.1016/j.renene.2015.06.066.

[10] Hassanudin, L. (2018). Analisis potensi pembangkit listrik tenaga angin, Jurnal Tenik Elektro, 7(1), 35-45. 
[11] Supadi, S. (2007). Ketersediaan debit air untuk irigasi pedesaan sungai Cipeles Jawa Barat, Jurnal Media Komunikasi Teknik Sipil, 3, 308-313.

[12] Tangkudung, H. (2011). Pengukuran kecepatan aliran dengan menggunakan pelampung dan current meter, Jurnal TEKNO, 9(55), 28-31.

[13] Krisnayanti, D.S., Hunggurami, E. \& Dhima-Wea, K.N.
(2017). Perencanaan drainase kota Seba, Jurnal Teknik Sipil, 6(1), 89-102.

[14] Rendi, R., Arifin, J., Mujiburrahman, M. \& Trianiza, I. (2020). Potensi pembangkit listrik tenaga air mikrohidro di sungai Pintab dan sungai Amandit Kalimantan Selatan, Jurnal Enginei, Manufaktur dan Material, 4(2), 46-52. 